\title{
Forage yield and quality on soil subjected to phosphorus rates in subtropical grassland of Brazil
}

\author{
Lorena de Miranda Mazza ${ }^{1}$, Antonio Carlos Vargas Motta ${ }^{2}$, Anibal de Moraes ${ }^{3}$, Fabiane \\ Machado Vezzani ${ }^{2}$, Paulo Fernando Adami ${ }^{4}$, Diego de Oliveira Rabel ${ }^{5}$ \\ ${ }^{1}$ Curso de Mestrado em Ciência do Solo da Universidade Federal do Paraná. \\ 2 Departamento de Solos e Engenharia Agrícola da Universidade Federal do Paraná. \\ ${ }^{3}$ Departamento de Fototecnia e Fitossanitarismo da Universidade Federal do Paraná \\ 4 Programa de Pós-Graduação em Agronomia - Produção Vegetal do Departamento de Fitotecnia e Fitossanitarismo da Universidade Federal \\ ${ }^{5}$ Curso de Agronomia da Universidade Federal do Paraná.
} do Paraná.

\begin{abstract}
Phosphorous application effects were evaluated on ryegrass dry matter (DM) accumulation, root development and plant tissue concentration of phosphorus, nitrogen and carbon aiming to determinate the nutritional status of the pasture, as well as to verify the possibility to establish a phosphorus dilution curve for this pasture. Also, the development of phosphorus and ryegrass cultivated with the residual effect of phosphorus fertilization was determined. The experiment was carried out in Pinhais County - Paraná State on a Cambisol with very low phosphorus levels. The experiment was of random blocks design and treatments consisted of five phosphorus rates of triple superphosphate $\left(0,45,90,180\right.$ and 360 kg $\mathrm{P}_{2} \mathrm{O}_{5}$ ha-1) applied to soil surface with four replications. Phosphorus fertilization promoted linear increments in the soil phosphorus availability and resulted, in the first year, in early pasture production and higher phosphorus content in the plant. Nitrogen and carbon contents were not affected. Phosphorous application increased ryegrass DM accumulation in all periods, ranging from 16 to $2826 \mathrm{~kg} \mathrm{DM} \mathrm{ha}^{-1}$ at flowering stage, for zero and $360 \mathrm{~kg} \mathrm{P}_{2} \mathrm{O}_{5} \mathrm{ha}^{-1}$, respectively. Root density was positively influenced by phosphorus supply, and the rate of $45 \mathrm{~kg} \mathrm{P}_{2} \mathrm{O}_{5} \mathrm{ha}^{-1}$ was effective for maximum root development. The residual effect of phosphorus fertilizer provided enhancement of yield and phosphorus plant concentration for both sorghum and ryegrass in the second year.
\end{abstract}

Key Words: Lolium multiflorum, phosphorous dilution curve, phosphorous fertilization, shoot/root ratio, sorghum silage

\section{Introduction}

Brazil stands out in the world scenario by having the largest commercial cattle herd reared exclusively on pasture (Martha \& Corsi, 2001). However, most of these pasture areas are under soils with low P levels, and this nutrient is of greater economic relevance in cattle grazing systems since the occurrence of $\mathrm{P}$ animal deficiency has been intensively reported (Tokarnia et al., 2000). Based on that, it is possible to assume that phosphorus is one of the most limiting nutrients to pasture production in Brazil (Gatiboni et al., 2000; Gatiboni et al., 2003; Bandinelli et al., 2005), especially due to low use of fertilizer on Brazilian pastures.

It is known that phosphorus (P) availability in soil leads to higher pasture dry matter accumulation (Gheri et al., 2000; Mesquita et al., 2004; Melo et al., 2007), due to the positive influence on tillering (Cecato et al., 2000), thereby increasing the amount of fodder available. Phosphorous fertilization also increases plant tissue $\mathrm{P}$ content and consequently, the quality of forage (Schunke et al., 1991). Another positive effect of $\mathrm{P}$ is the greater development of roots, both in length, surface and total mass yield (Mesquita et al., 2004; Melo et al., 2007).

The accuracy of $\mathrm{P}$ fertilizer recommendations is essential for sustainable crop production. However, some reports indicate that soil analyses are poor predictors of crop $\mathrm{P}$ requirements under field conditions (Heckman et al., 2006). There are authors that propose the search for complementary techniques, such as leaf analysis and mathematical models which indicate nutrients limiting levels for the plant (Lemaire \& Salette, 1984; Thélier-Huché et al., 1999).

Based on that, the aim of this study was to understand the influence of increasing soil $P$ levels on ryegrass dry matter (DM) accumulation, root development and phosphorus $(\mathrm{P})$, nitrogen $(\mathrm{N})$ and carbon $(\mathrm{C})$ content in plant tissue in a way that it might contribute to the assessment of a $\mathrm{P}$ dilution curve to ryegrass. Also, the residual effect of phosphorus on sorghum and ryegrass was evaluated. 


\section{Material and Methods}

The experiment was carried out in Pinhais County, Paraná, from May 2009 to September 2009. The experimental area consisted of native grassland on a Cambisol (Embrapa, 2006) with very low initial levels of $P\left(1.6 \mathrm{mg} \mathrm{dm}^{-3}\right.$ - Mehlich I extraction) and average K levels (0.13 - Mehlich I extraction). The average month temperature and rainfall during the experimental period were $12^{\circ} \mathrm{C}$ and $150 \mathrm{~mm}$, respectively.

Ryegrass was sowed on May 26th of 2009 and fertilization was broadcast applied at the same time using $200 \mathrm{~kg} \mathrm{ha}^{-1}$ of $\mathrm{N}$ and $120 \mathrm{~kg} \mathrm{ha}^{-1}$ of $\mathrm{K}_{2} \mathrm{O}$, using urea and $\mathrm{KCl}$ as a source, respectively. After it, triple superphosphate $\left(\mathrm{P}_{2} \mathrm{O}_{5}-41 \%\right)$ was manually broadcast in each plot using its respective levels to each treatment. The experiment was laid out as random block design with four replications and treatments consisted of five $P$ rates $(0,45,90,180,360 \mathrm{~kg}$ $\left.\mathrm{P}_{2} \mathrm{O}_{5} \mathrm{ha}^{-1}\right)$ distributed in plots of $50 \mathrm{~m}^{2}$ each $(10 \times 5 \mathrm{~m})$.

Ryegrass shoot biomass evaluations in the first year started on July 31st or 52 days after its emergence when plants reached $500 \mathrm{~kg} \mathrm{ha}^{-1}$ of DM. From these period on, ryegrass shoot biomass was sampled weekly for 7 weeks or at 59, 66, 73, 80, 87, 94 and 101 days after ryegrass emergence, aiming to evaluate the plants development up to its flowering stage (September 18th of 2009). The goal of periodic sampling was to obtain the dilution curve for P. Samples consisted of cutting whole plants in 2 square meters $(0.5 \times 4.0 \mathrm{~m})$ of each plot at $5 \mathrm{~cm}$ of the ground using a pruning scissors and a metal square. Dry matter accumulation was evaluated at all sampling periods. Samples were dried in a forced-ventilation oven at $60{ }^{\circ} \mathrm{C}$ until constant weight to determine the dry matter forage production. After this, samples were used to determine the $\mathrm{P}, \mathrm{N}$ and $\mathrm{C}$ content of all collected samples.

Phosphorous concentrations in plant tissue were measured by the methodology described by Martins \& Reissmann (2007). Nitrogen and carbon contents were obtained by dry combustion using the apparatus VARIO EL III - Elementary ${ }^{\circledR}$. Nitrogen levels were used to estimate crude protein (CP), considering that there is $16 \%$ of $\mathrm{N}$ into the proteins (Jones, 1931).

Tillering was assessed at the flowering moment collecting one sample of $20 \times 15 \mathrm{~cm}\left(0.03 \mathrm{~m}^{2}\right)$, in each plot. All the tiller samples were counted and their number was transformed into tiller per $\mathrm{m}^{2}$. The average weight of each tiller was obtained after drying the sample and dividing the dry mass by the number of tillers.

Ryegrass roots were evaluated on October 2nd, collecting three samples of soil and then roots per plot, using a cylinder of $1.57 \mathrm{dm}^{3} 10$-cm high. Roots were submitted to the WinRhizo equipment to evaluate the diameter, length and root volume. The length obtained by the device was used to calculate the root density obtained by dividing the root length $(\mathrm{cm})$ by the volume of soil sampled $\left(\mathrm{cm}^{3}\right)$.

Establishment of the phosphorous dilution curve was possible through the derivation of the dry matter accumulation regression curves of each period, which also allowed obtaining the maximum point and consequently the levels of $\mathrm{P}$ that promoted the highest dry matter accumulation in each of these periods. From the dry matter accumulation $\left(\mathrm{kg} \mathrm{ha}^{-1}\right)$ data and its phosphorous content $\left(\mathrm{g} \mathrm{kg}^{-1}\right)$, it was possible to determine the critical phosphorus dilution curve for ryegrass, or the increase in the $\mathrm{P}$ content per kg of DM along the time.

In November 2009, the forage sorghum was sown over the same plots which were occupied by ryegrass, receiving only nitrogen fertilizer with $200 \mathrm{~kg} \mathrm{ha}^{-1}$ of $\mathrm{N}$ as urea. Sorghum sowing was made mechanically over ryegrass straws with $50 \mathrm{~cm}$ width between row and $20 \mathrm{~cm}$ between plants. In March 2010, when the sorghum reached the flowering period, four meters of the two central rows of each plot were hand-harvested. The plant materials were weighed fresh, subsampled, weighed fresh again, washed, dried (constant weight at $60^{\circ} \mathrm{C}$ ), weighed dry, ground (Wiley mill), and analyzed for P.

In May 2010, the sorghum was mown and the residue was incorporated into the soil, by disking the soil twice. In June 2010, ryegrass was sown by broadcasting $90 \mathrm{~kg} \mathrm{ha}^{-1}$ of seed. The ryegrass received three applications of $50 \mathrm{~kg} \mathrm{ha}^{-1}$ of $\mathrm{N}$ as urea. The first application was made after sowing and the others on 08/03/2010 and 09/10/2010, respectively. The plot was harvested every time that plant reached $40 \mathrm{~cm}$ height. Four random samples were clipped at $5 \mathrm{~cm}$ within a square area of $0.25 \mathrm{~m}^{2}$ in each plot. After sampling, the whole plot was mowed at $15 \mathrm{~cm}$ height in order to standardize the plant height. The maximum number of samples was three on 08/17/2010; 09/14/2010 and 10/22/2010. As a result of $\mathrm{P}$ treatments, especially for the lower $\mathrm{P}$ rates, not all the treatment reached $40 \mathrm{~cm}$ height, in all sample dates. Only the plots which received the rates of 180 and $360 \mathrm{~kg} \mathrm{P}_{2} \mathrm{O}_{5}$ ha $^{-1}$ were harvested three times. The plots that received 45 and $90 \mathrm{~kg} \mathrm{P}_{2} \mathrm{O}_{5}$ ha $^{-1}$ were harvested twice, while the check which never reached $40 \mathrm{~cm}$ height was harvested once, during last harvest of the two highest $\mathrm{P}$ rates.

The $\mathrm{P}$ concentration for sorghum and ryegrass was determined following the same methodology used for the first year, as described before.

Dry matter accumulation, P concentration in plant tissue, tillering, phosphorus dilution curve, and shoot/root ratio were subjected to regression analysis. Data relating to the 
roots and the $\mathrm{N}$-content were submitted to the comparison of means by Duncan test. Analyses were performed using the statistical program ASSISTAT (version 7.5 beta 2010).

\section{Results and Discussion}

Phosphorus fertilization promoted a linear increase in the soil available phosphorus (Figure 1), reaching about $8.6 \mathrm{mg} \mathrm{dm}^{-3}$ at the highest $\mathrm{P}$ fertilization rate $\left(360 \mathrm{~kg} \mathrm{P}_{2} \mathrm{O}_{5} \mathrm{ha}^{-1}\right)$, or medium concentration levels after the experiment while the control remained with only $1.4 \mathrm{mg} \mathrm{dm}^{-3}$ or low level classification, according to the Soil Fertilization Manual, CFSRS/SC (2004).

However, ryegrass plant tissue $\mathrm{P}$ concentration also increased in all the periods in the first experimental year. Maximum $\mathrm{P}$ concentration was obtained by applying $250 \mathrm{~kg} \mathrm{P}_{2} \mathrm{O}_{5} \mathrm{ha}^{-1}$ for all assessments from the 3rd period, or at 66 days after germination (Figure 2).

Results (Figure 2) indicate that it is possible to achieve $\mathrm{P}$ tissue reasonable values above the mean value $\left(1.3 \mathrm{~g} \mathrm{~kg}^{-1}\right.$ of P), as reported by Trindade \& Cavalheiro (1990) on 568 pasture samples of native grassland soils, as used in this study. This data also indicate an improvement in the quality of native grassland pasture by the cultivation of ryegrass together with phosphorus supply. However, the mere introduction of this species in these soils, without fertilization, might turn out in lower $P$ availability to animal, since ryegrass in the treatment without $P$ reaches average of only $0.9 \mathrm{~g} \mathrm{~kg}^{-1}$.

Considering beef cattle mineral requirements of $3 \mathrm{~g} \mathrm{~kg}^{-1}$ of P (NRC, 1996) for its growth and finishing, phosphorus levels of 180 and $360 \mathrm{~kg} \mathrm{P}_{2} \mathrm{O}_{5}$ ha $^{-1}$ would be enough to meet this requirement in almost all the periods (Figure 2).

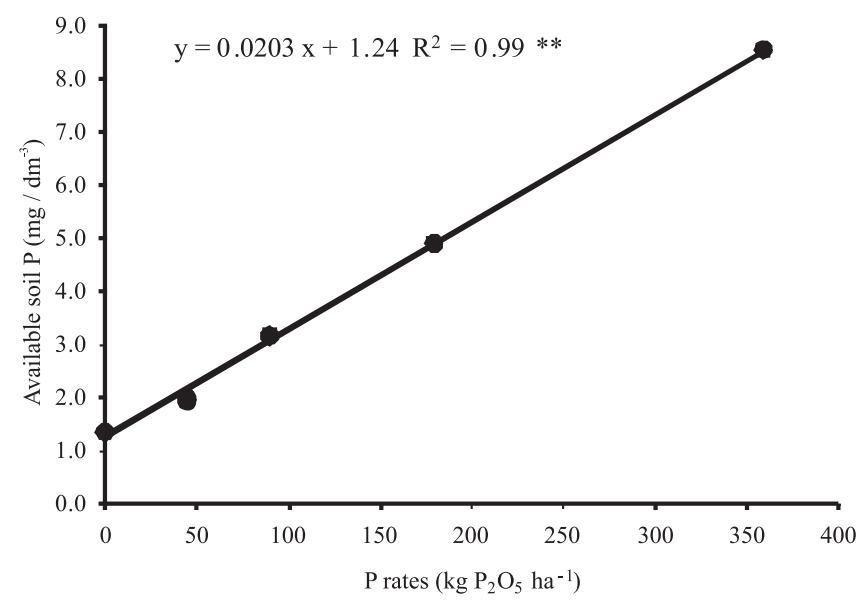

Figure 1 - Phosphorus extracted by Mehlich I in soil samples $\left(\mathrm{mg} \mathrm{dm}^{-3}\right)$ as related to $\mathrm{P}$ rates in a Cambisol in the subtropical region of Brazil.
On the other hand, $\mathrm{N}$ and $\mathrm{C}$ content in the ryegrass tissue were not influenced by the $\mathrm{P}$ rates (Table 1 ). Plants without $\mathrm{P}$ application showed higher $\mathrm{N}$ values along the evaluations, except at the first, 52 days after emergence. This might be explained by the $\mathrm{N}$ dilution in the $\mathrm{DM}$ production along the experiment. Treatments with $\mathrm{P}$ fertilization showed higher dry matter production and consequently, $\mathrm{N}$ was diluted into this higher production. With the control, the opposite happened, once its growth was compromised since the first evaluation period and the dilution did not occur, keeping almost the same values of $\mathrm{N}$ until the last period and so it showed higher levels of $\mathrm{N}$.

Despite the small difference between $\mathrm{N}$ concentrations between treatments, it is important to note that there were significant differences in $\mathrm{kg}$ of $\mathrm{N}$ uptake, since fertilized plants accumulated more dry matter and consequently the amount of $\mathrm{N}$ absorbed per area became much greater for plants under increasing rates of $\mathrm{P}$. This fact confirms a higher $\mathrm{N}$ uptake by the use of $\mathrm{P}$ fertilization, which brings benefits such as higher crude protein production per hectare (Table 1). It was also noted that P levels of 180 and $360 \mathrm{~kg}$ $\mathrm{P}_{2} \mathrm{O}_{5}$ ha $^{-1}$ caused the highest accumulation of CP up to 80 days after germination and from this period on, lower $P$ rates (45 and $90 \mathrm{~kg} \mathrm{P}_{2} \mathrm{O}_{5} \mathrm{ha}^{-1}$ ) reached the same $\mathrm{CP}$ accumulation.

Ryegrass dry matter carbon content remained constant around $40 \%$ of DM along the experiment periods and among treatments, which shows the great potential of this plant to insert carbon into the system, especially under P levels once its highest rates $\left(360 \mathrm{~kg} \mathrm{P}_{2} \mathrm{O}_{5} \mathrm{ha}^{-1}\right.$ ) increased ryegrass dry matter production to a level able to add approximately $1 \mathrm{Mg} \mathrm{Cha}^{-1}$ considering only its aerial parts during the fall/ winter (Table 1).

There were difficulties in assessing the dry matter production of control since its germination and growth were compromised due to very low soil P condition $\left(1.6 \mathrm{mg} \mathrm{dm}^{-3}\right)$, showing a forage sward with small clumps in isolated portions of the plot. Furthermore, low P availability was noticed at the soil chemical analyses, affecting plants development, as confirmed by the positive effect of phosphorus fertilization levels over ryegrass dry matter accumulation along the periods (Figure 3 ).

Ryegrass response to $\mathrm{P}$ levels varied along the crop cycle (Figure 3 ). In the 1st and 2nd periods (60 days after emergence), there was a linear dry matter accumulation fit. From the 3rd period on, the dry matter accumulation response showed a quadratic curve from $90 \mathrm{~kg}$ of $\mathrm{P}_{2} \mathrm{O}_{5} \mathrm{ha}^{-1}$. These results show that phosphorus fertilization in soils with poor P levels might anticipate the first grazing, reducing the lack of forage in the fall and decreasing costs on supplements or conserved forage. Some studies also report this precocity 
1st period

(52 days after emergence)

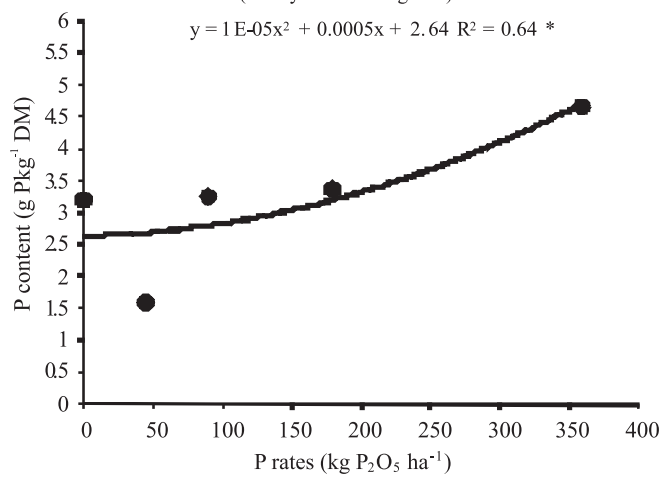

3rd period

(66 days after emergence)

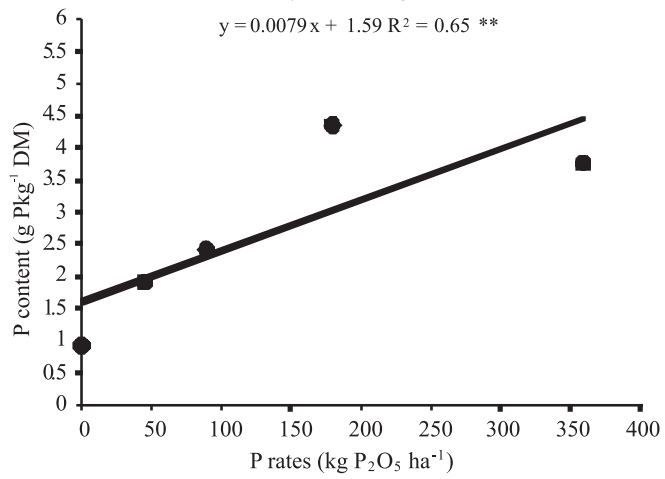

5 th period

(80 days after emergence)

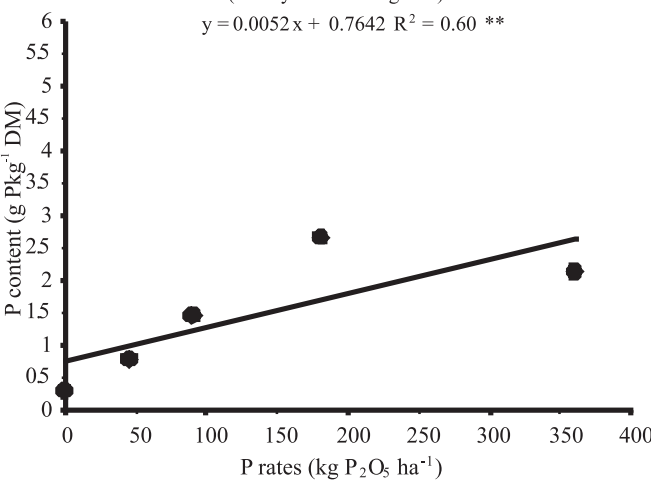

7th period

(94 days after emergence)

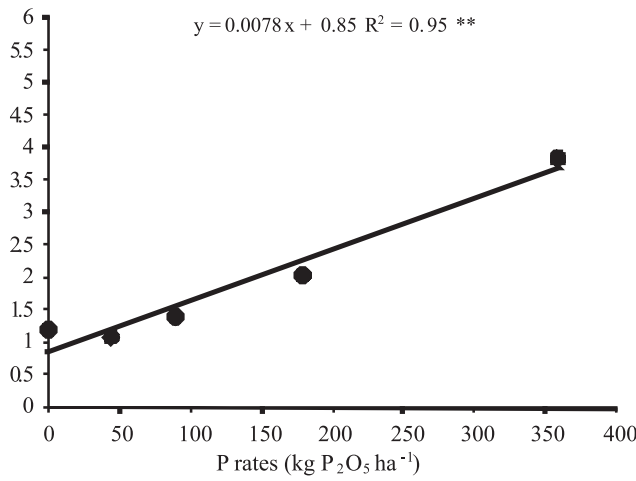

2nd period

(59 days after emergence)

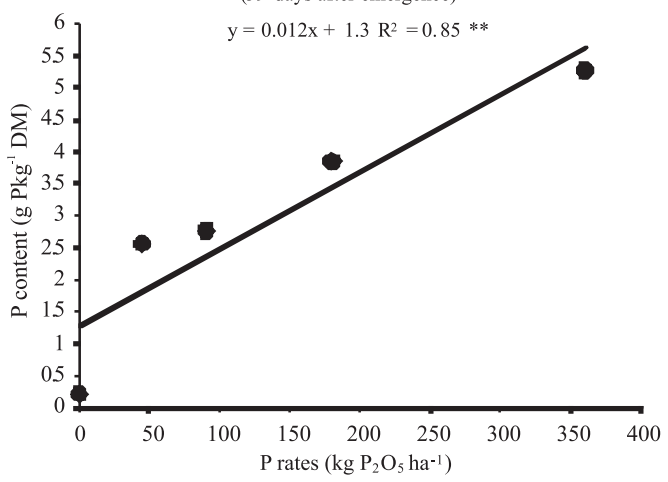

4th period

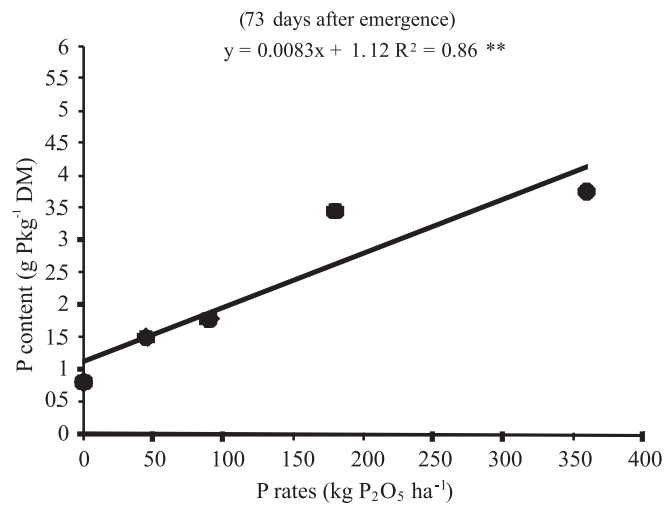

6th period

(87 days after emergence)

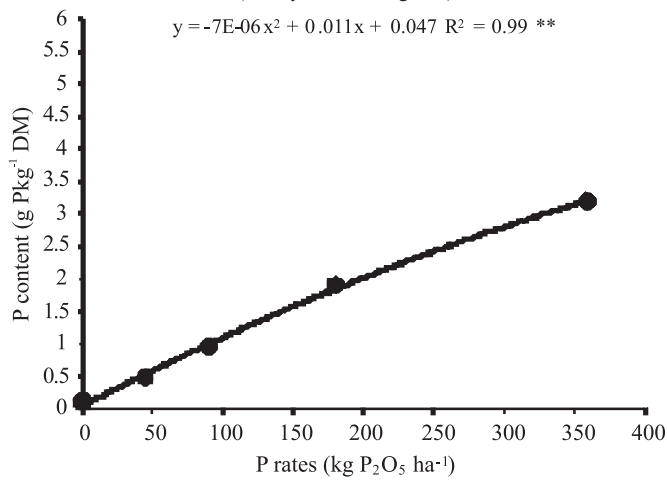

8th period

(101 days after emergence)

$\mathrm{y}=0.0044 \mathrm{x}+0.50 \mathrm{R}^{2}=0.80 * *$

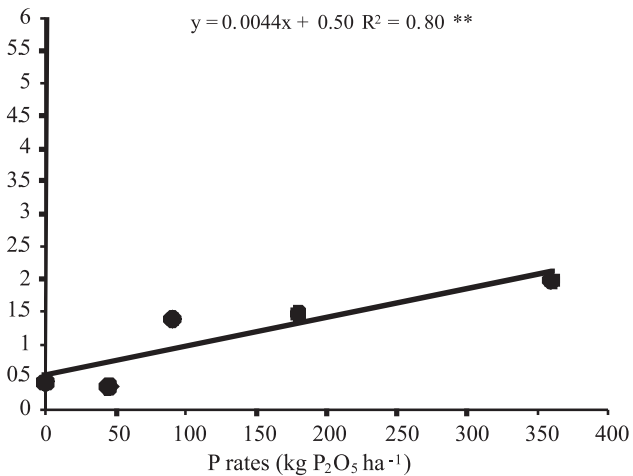

Figure 2 - Phosphorus concentration on ryegrass tissue $\left(\mathrm{g} \mathrm{kg}^{-1} \mathrm{of} \mathrm{P}\right)$ along with sampling periods in relation to phosphorous fertilization in a Cambisol in the subtropical region of Brazil. 
Table 1 - Ryegrass N ( $\mathrm{g} \mathrm{kg}^{-1}$ ) and C (\%) content and crude protein (CP) and C uptake in relation to phosphorous fertilization rates in a Cambisol in the subtropical region of Brazil

\begin{tabular}{|c|c|c|c|c|c|c|c|c|}
\hline \multirow{3}{*}{$\begin{array}{l}\text { Treatment } \\
\mathrm{kg} \mathrm{P}_{2} \mathrm{O}_{5} \text { ha }^{-1}\end{array}$} & \multicolumn{8}{|c|}{ Plant tissue content } \\
\hline & \multicolumn{8}{|c|}{ Days after emergence } \\
\hline & 52 & 59 & 66 & 73 & 80 & 87 & 94 & 101 \\
\hline & * & $* *$ & $* *$ & $\begin{array}{l}\text { Signi } \\
* *\end{array}$ & $\begin{array}{r}\text { level } \\
* *\end{array}$ & $* *$ & ns & $* *$ \\
\hline 0 & $5.7 \mathrm{ab}$ & $6.5 \mathrm{a}$ & $5.9 \mathrm{a}$ & $6.4 \mathrm{a}$ & $5.3 a$ & $4.9 \mathrm{a}$ & $3.0 \mathrm{a}$ & $5.0 \mathrm{a}$ \\
\hline 180 & $5.5 b$ & $4.9 b$ & $4.1 \mathrm{~b}$ & $3.8 \mathrm{~b}$ & $3.1 \mathrm{bc}$ & $3.0 \mathrm{~b}$ & $2.6 \mathrm{a}$ & $2.1 \mathrm{~b}$ \\
\hline \multirow[t]{4}{*}{360} & $5.5 b$ & $4.2 \mathrm{c}$ & $3.9 b$ & $3.6 b$ & $2.6 \mathrm{c}$ & $3.0 \mathrm{~b}$ & $2.9 \mathrm{a}$ & $2.4 \mathrm{~b}$ \\
\hline & \multicolumn{8}{|c|}{ C (\%) } \\
\hline & \multicolumn{8}{|c|}{ Significance level } \\
\hline & ns & ns & ns & $*$ & $*$ & ns & ns & ns \\
\hline 360 & 41 & 38 & 40 & $40 \mathrm{~b}$ & $39 b$ & 38 & 39 & 39 \\
\hline \multirow{4}{*}{ kg $\mathrm{P}_{2} \mathrm{O}_{5} \mathrm{ha}^{-1}$} & \multirow{2}{*}{\multicolumn{8}{|c|}{$\begin{array}{c}\text { Accumulation }\left(\mathrm{kg} \mathrm{ha}^{-1}\right) \\
\text { CP }\end{array}$}} \\
\hline & & & & & & & & \\
\hline & \multicolumn{8}{|c|}{ Significance level } \\
\hline & $* *$ & $* *$ & $* *$ & $* *$ & $* *$ & $* *$ & $* *$ & $* *$ \\
\hline 0 & 1d & $2 \mathrm{~d}$ & $2 c$ & 3d & $3 d$ & $4 \mathrm{c}$ & $2 \mathrm{c}$ & $5 b$ \\
\hline 45 & $57 c d$ & $107 c$ & $180 \mathrm{~b}$ & $286 c$ & $189 \mathrm{c}$ & $159 b$ & $275 c$ & $281 \mathrm{a}$ \\
\hline 90 & $99 \mathrm{bc}$ & $166 \mathrm{bc}$ & $245 b$ & $438 b$ & $241 b c$ & $292 a$ & $337 a b$ & $386 a$ \\
\hline 180 & $140 \mathrm{ab}$ & 233ab & $429 a$ & $536 a b$ & $388 a$ & $338 \mathrm{a}$ & $306 b$ & $379 a$ \\
\hline \multirow[t]{2}{*}{360} & $188 \mathrm{a}$ & $251 \mathrm{a}$ & $394 a$ & $569 a$ & $341 \mathrm{ab}$ & $374 a$ & $436 a$ & $429 a$ \\
\hline & \multicolumn{8}{|c|}{$\begin{array}{c}\text { C } \\
\text { Significance level }\end{array}$} \\
\hline
\end{tabular}

** significant at $1 \%$ probability $(\mathrm{P}<0.01)$.

* significant at $5 \%$ probability $(0.01 \geq \mathrm{P}<0.05)$.

ns not significant $(\mathrm{P} \geq 0.05)$.

Means followed by same letter do not differ by the Duncan test.

to other grasses such as maize (Welch \& Boone, 1968), wheat (Brandon et al., 1981) and barley (Zada \& Karim, 1982).

Ryegrass dry matter maximum accumulation was around $2850 \mathrm{~kg} \mathrm{ha}^{-1}$ at the flowering stage (101 days after germination; Figure 3). This value can be considered significant, suggesting the great potential of this species when compared with the production of native grasslands, which can produce around $4000 \mathrm{~kg} \mathrm{DM} \mathrm{ha}^{-1} \mathrm{yr}^{-1}$ (Maraschin et al., 1997) but only $235 \mathrm{~kg} \mathrm{DM} \mathrm{ha}^{-1}$ during the winter (Rizo et al., 2004), accounting with several cuts.

It is noteworthy that there were no cuts in this experiment and that this production refers only to an interval of 100 days, which demonstrates the superiority of ryegrass as an alternative for the winter. On the other hand, DM accumulation in the treatment without $\mathrm{P}$ supply was negligible and rather low from those values reported for native grasslands. Thus, the common practice of simply introducing ryegrass in native grasslands (soils with low $\mathrm{P}$ level) without $\mathrm{P}$ supply, as in the case of the control treatment is not indicated, once it may even hamper the forage supply for grazing animals during winter.

Increasing dry mass accumulation showed a positive correlation with P availability in the soil up to $6.8 \mathrm{mg} \mathrm{dm}^{3}$ (Figure 4).

Increasing dry matter with phosphorus fertilization was a result of heavier tillers and not due to a higher number of tillers (Figure 5). Tiller mass showed a linear increase as phosphorous levels increased. The highest $\mathrm{P}$ rate $(360 \mathrm{~kg}$ $\mathrm{P}_{2} \mathrm{O}_{5} \mathrm{ha}^{-1}$ ) resulted in average tillers of $0.45 \mathrm{~g}$ versus $0.3 \mathrm{~g}$ at the $\mathrm{P}$ rate of $45 \mathrm{~kg} \mathrm{~kg} \mathrm{P}_{2} \mathrm{O}_{5}$ ha $^{-1}$ (Figure 5). 
1st period

(52 days after emergence)

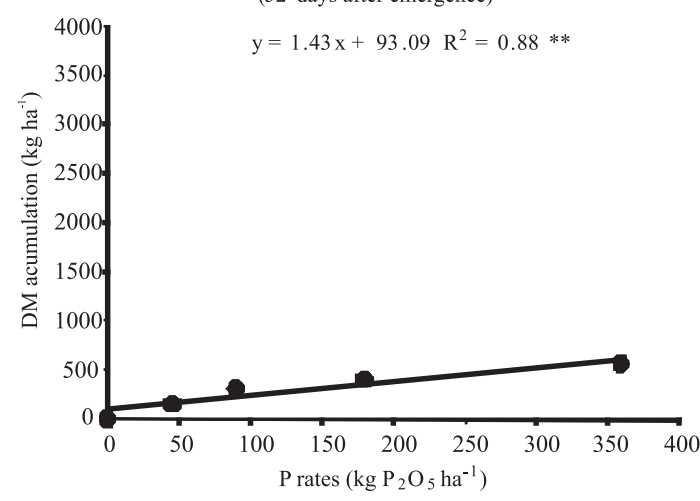

3rd period

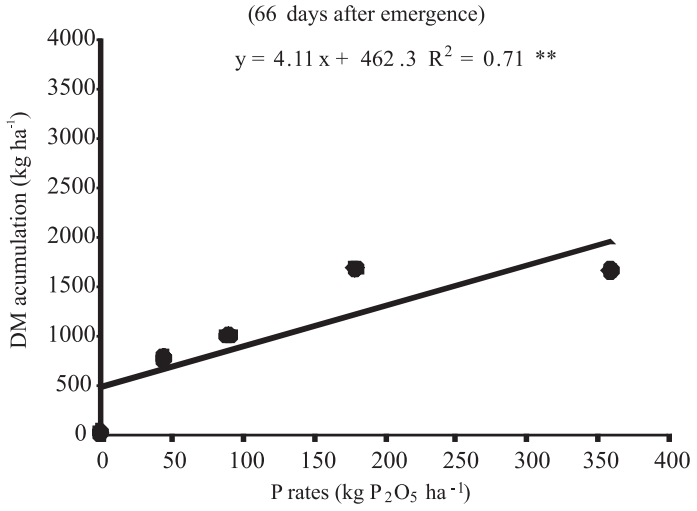

5 th period

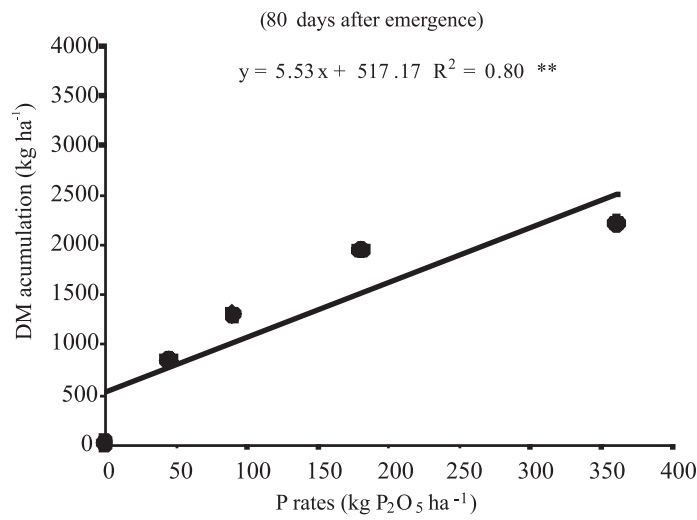

7th period

(94 days after emergence)

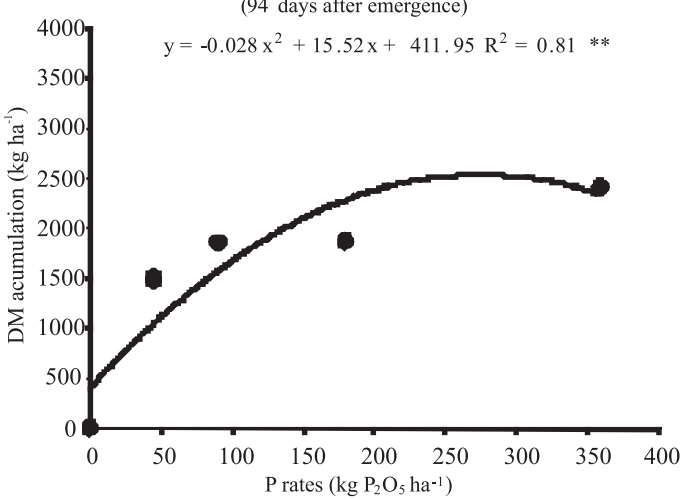

2nd period

(59 days after emergence)

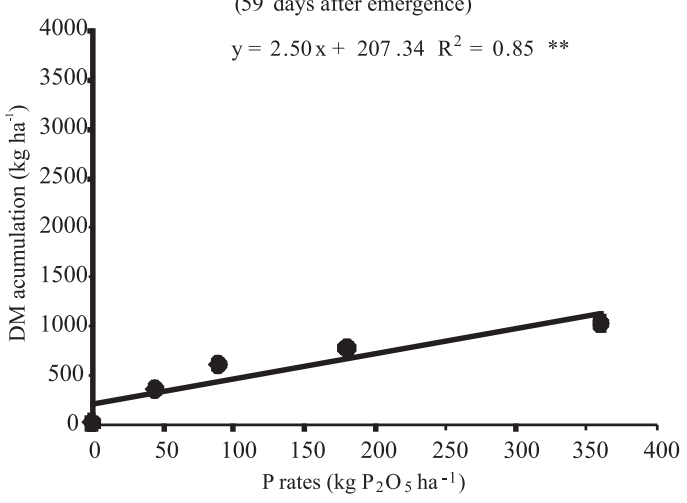

4th period

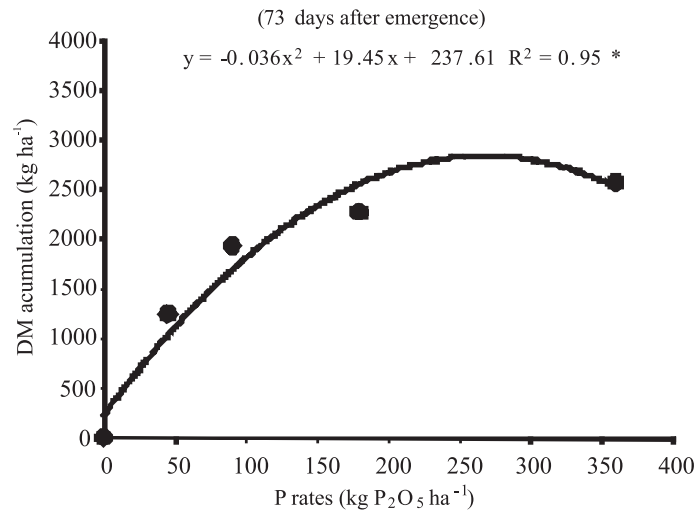

6th period

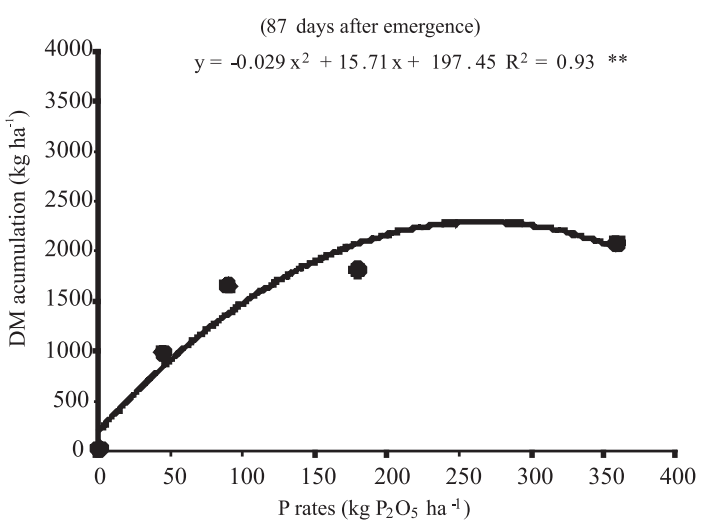

8th period

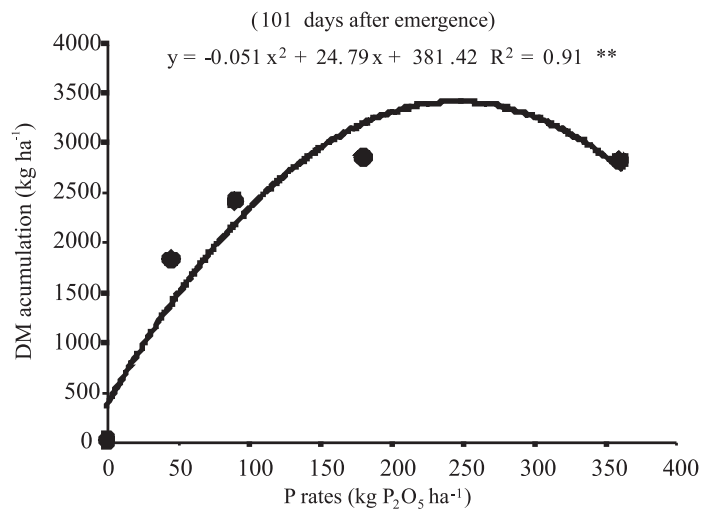

Figure 3 - Ryegrass dry matter accumulation ( $\mathrm{kg} \mathrm{DM} \mathrm{ha}^{-1)}$ along sampling periods, in relation to phosphorous fertilization levels for a Cambisol in the subtropical region of Brazil. 
Ryegrass plant growth at the treatment without $\mathrm{P}$ was impaired by lower plant tillering and slow growth immediately after emergence, remaining so until the end of the assessment. Experimental data show that $45 \mathrm{~kg} \mathrm{P}_{2} \mathrm{O}_{5} \mathrm{ha}^{-1}$ are enough to influence tillering. Oliveira et al. (2004) and Cecato et al. (2008) reported results similar to this study, with an increase in the mass of tillers without changing their number. These observations from this experiment disagree with Cecato et al. (2000), Mesquita et al. (2004), Manarin (2005) and Melo et al. (2007), who reported an increase in the number of tillers as regarding to summer grasses response to $\mathrm{P}$ rates.

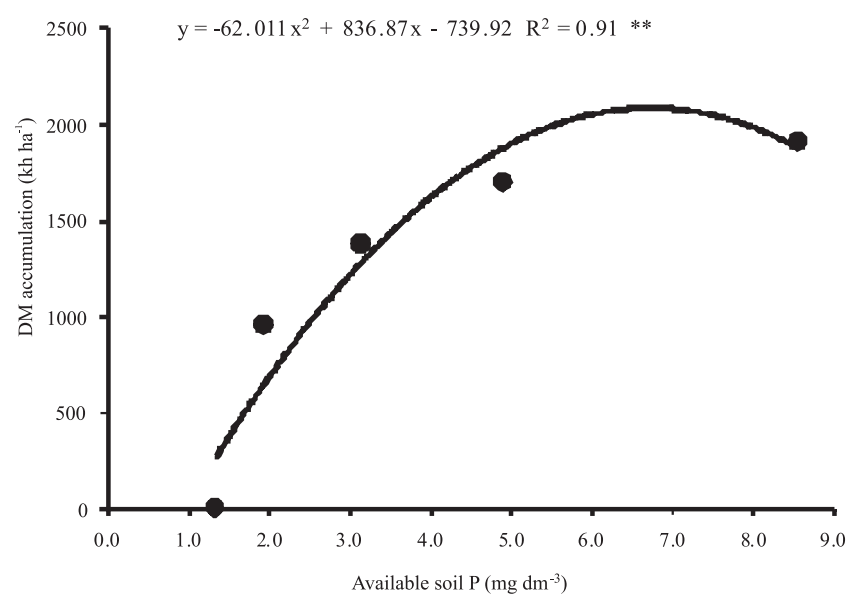

Figure 4 - Soil phosphorus availability (Mehlich I) effect over ryegrass dry matter accumulation in a Cambisol in the subtropical region of Brazil.

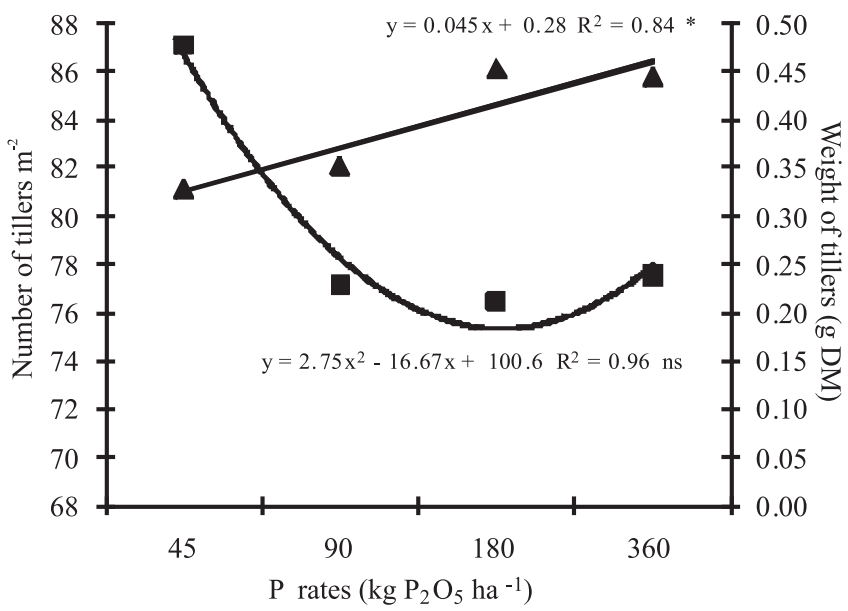

Number of tillers $\quad \boldsymbol{\Delta}$ Weight of tillers

Figure 5 - Number (units $\mathrm{m}^{-2}$ ) and weight (g DM) of ryegrass tillers at the end of the cycle in relation to phosphorous fertilization in a Cambisol in the subtropical region of Brazil.
Ryegrass roots development was positively influenced by P rates showing a higher total root length $(\mathrm{cm})$ as well as a higher density of roots in the soil $\left(\mathrm{cm} \mathrm{cm}^{-3}\right)$. However, volume and average root diameter did not differ between $\mathrm{P}$ levels, while root density increased due to the P supply differing from the control treatment (Table 2).

Results demonstrate that even low $\mathrm{P}$ rates such as $45 \mathrm{~kg} \mathrm{P}_{2} \mathrm{O}_{5}$ ha $^{-1}$ are enough to ensure good root development. Thus confirming that the addition of phosphorus can promote better root development and as a consequence, higher root density (root $\mathrm{cm} / \mathrm{cm}^{3}$ of soil), which, in turn, has a greater capacity to explore more soil and probably absorb more water and nutrients, thus increasing the production capacity of the pasture.

Ryegrass shoot and roots development showed a positive response to the application of $\mathrm{P}$, although phosphorus fertilization promoted a higher production of the ryegrass shoot, corroborating to the results reported by Mesquita et al. (2004). Root density reached its maximum gain at the lowest $\mathrm{P}$ rate $\left(45 \mathrm{~kg} \mathrm{P}_{2} \mathrm{O}_{5} \mathrm{ha}^{-1}\right)$, while shoot dry matter accumulation was positively influenced up to $250 \mathrm{~kg}$ $\mathrm{P}_{2} \mathrm{O}_{5}$ ha $^{-1}$.

Regarding ryegrass plants shoot and root ratio (Figure 6), it is possible to observe that plants in the absence of phosphorus invested in root growth instead of dry matter accumulation in shoots. Several studies show results similar (Rosolem \& Marcello, 1998; Bhadoria et al., 2004; Olszewska et al., 2008), to the observed in this experiment, proving that roots development happens even under low $\mathrm{P}$ rates. Furthermore, the similar root volume and average diameter support this idea. Shenk \& Barber (1977) reported that corn in a situation of lack of $P$, increased its roots contact surface as a strategy to absorb $\mathrm{P}$ under low $\mathrm{P}$ availability. This helps to explain the relationship between shoot and root of 0.04 for the control, showing a greater development of root system instead of the shoot.

On the other side, plants fertilized with P (from $90 \mathrm{~kg}$ $\mathrm{P}_{2} \mathrm{O}_{5} \mathrm{ha}^{-1}$ ), showed a shoot/root ratio above 1.0 , indicating

Table 2 - Ryegrass root parameters in relation to phosphorus fertilization rates in a Cambisol in the subtropical region of Brazil

\begin{tabular}{cccc}
\hline Treatment & $\begin{array}{c}\text { Mean } \\
\text { diameter (ns) }\end{array}$ & $\begin{array}{c}\text { Root } \\
\text { volume (ns) }\end{array}$ & $\begin{array}{c}\text { Density } \\
(*)\end{array}$ \\
\cline { 2 - 4 } $\mathrm{kg} \mathrm{P}_{2} \mathrm{O}_{5}$ ha $^{-1}$ & $\mathrm{~mm}$ & $\mathrm{~cm}^{3}$ & $\mathrm{~cm} \mathrm{~cm}{ }^{-3}$ \\
\hline 0 & 0.706 & 4.06 & $1.56 \mathrm{~b}$ \\
45 & 0.861 & 7.10 & $3.03 \mathrm{a}$ \\
90 & 0.921 & 8.18 & $2.92 \mathrm{a}$ \\
180 & 0.892 & 8.19 & $2.84 \mathrm{a}$ \\
360 & 0.872 & 6.75 & $2.88 \mathrm{a}$ \\
\hline
\end{tabular}

* significant at $5 \%$ probability $(0.01 \geq \mathrm{P}<0.05)$

ns - not significant $(\mathrm{P} \geq 0.05)$.

Means followed by same letter do not differ by the Duncan test. 
that plants cultivated in a soil with available $\mathrm{P}$ and without water deficit invest more in their shoot development, resulting in a root development similar to the control. This fact was reported by several authors, which demonstrates that under adequate P supply or availability, roots become less developed (Hajabbasi \& Shumacher, 1994; Kanno et al., 2001; Manarin, 2005).

Soil phosphorous availability (Mehlich I) also shows a direct relationship with ryegrass shoot/root ratio, suggesting that plants tend to invest in shoot growth as soil $\mathrm{P}$ availability increases until $8.8 \mathrm{mg} \mathrm{dm}^{-3}$ (Figure 7).

As ryegrass developed and dry mass accumulation increased, phosphorous tissue content decreased due to the dilution effect. Knowing the average $\mathrm{P}$ rate that promoted the maximum DM accumulation ( $290 \mathrm{~kg} \mathrm{P}_{2} \mathrm{O}_{5} \mathrm{ha}^{-1}$ ), it was

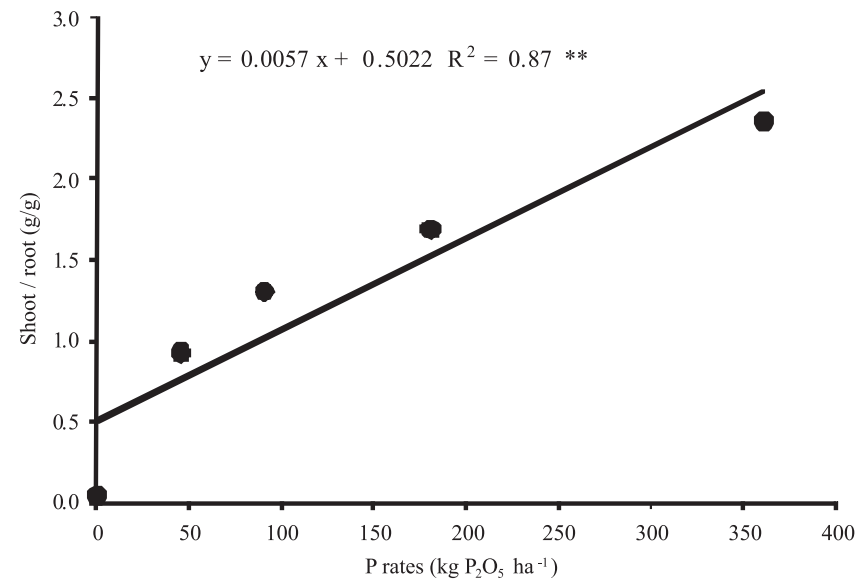

Figure 6 - Shoot/root ratio as related to phosphorous rates in a Cambisol in the subtropical region of Brazil.

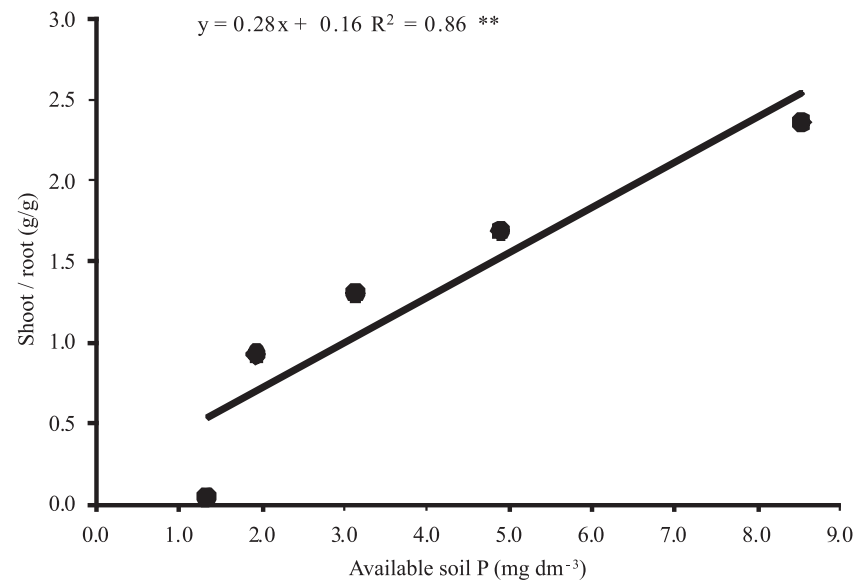

Figure 7 - Effect of soil phosphorus availability (Mehlich I) on shoot/root ratio in a Cambisol in the subtropical region of Brazil. possible to determine a phosphorous dilution curve to ryegrass (Figure 8), which corresponds, at any moment of vegetative growth, to the minimum concentration of $\mathrm{P}$ necessary to achieve maximum above ground biomass (Lemaire \& Salette, 1984).

The dilution curve discriminates three different types of $\mathrm{P}$ status. Below the curve, growth is limited by $\mathrm{P}$, above it, growth is not limited by $\mathrm{P}$ and on the curve, the $\mathrm{P}$ concentration is optimum. It is considered a useful tool to help the plants nutritional status diagnose along its growing season, since it indicates the appropriate content of $\mathrm{P}$ to achieve maximum above-ground biomass production, helping as a complement to the soil nutrient chemical analyses. Therefore, it would be possible, through curves like this, to determine the appropriate level of $\mathrm{P}$ in ryegrass. For instance, if $\mathrm{P}$ plant tissue analysis were done 80 days after ryegrass germination (with a DM accumulation of $2,300 \mathrm{~kg} \mathrm{ha}^{-1}$ ), the appropriate content of $\mathrm{P}$ to ensure maximum above-ground biomass would be close to $2.65 \mathrm{~g} \mathrm{~kg}^{-1}$, and values below this are characterized as $\mathrm{P}$ deficiency.

One must regard that this study intended to create a phosphorous dilution curve to ryegrass; however, to better characterize this curve, longer term studies in diverse environmental conditions, such as climate and soil are required in order to have a reliable curve as a tool for diagnosis of phosphorous nutritional status.

The $\mathrm{P}$ fertilizer applied previously boosted the sorghum yield as well as P concentration, showing the influence of $P$ residual effect (Figure 9). The dry matter accumulation showed quadratic response, achieving the maximum technical efficiency at $225 \mathrm{~kg}$ of $\mathrm{P}_{2} \mathrm{O}_{5} \mathrm{ha}^{-1}$, which is very close to the value of $250 \mathrm{~kg}$ of $\mathrm{P}_{2} \mathrm{O}_{5} \mathrm{ha}^{-1}$ observed for ryegrass in the first year crop. Value slight superior, of

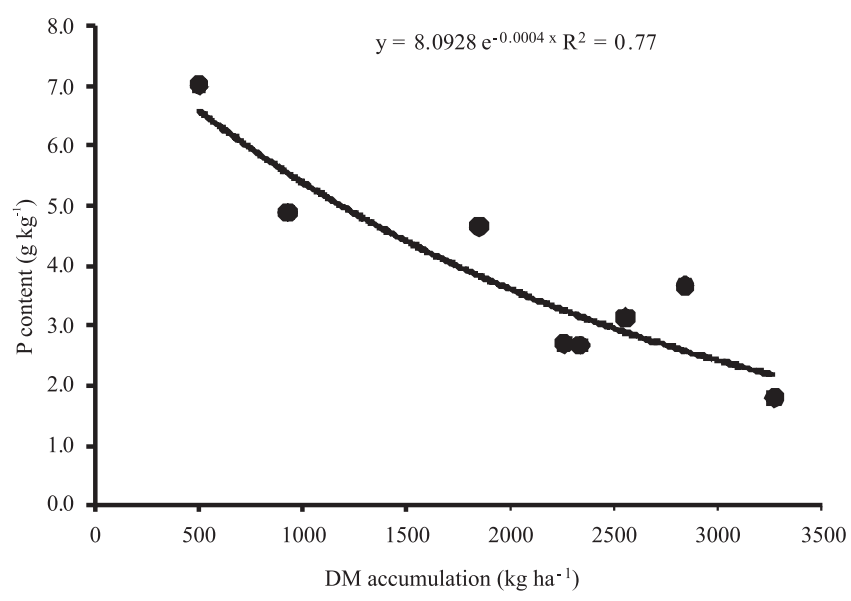

Figure 8 - Ryegrass phosphorus dilution curve in a Cambisol in the subtropical region of Brazil. 
Sorghum silage $\left(\mathrm{y}=-0.2357 \mathrm{x}^{2}+105.75 \mathrm{x}+1016.1 \mathrm{R}^{2}=0.97 *\right)$ $\rightarrow$ Ryegrass $\left(\mathrm{y}=8.84 \mathrm{x}+659.96 \quad \mathrm{R}^{2}=0.90 * *\right)$
- Sorghum silage $\left(\mathrm{y}=0.0071 \mathrm{x}+2.1557 \mathrm{R}^{2}=0.92 * *\right)$

Ryegrass $\left(-5 \mathrm{E}-06 \mathrm{x} 2+0.0076 \mathrm{x}+0.61 \mathrm{R}^{2}=0.94 *\right)$
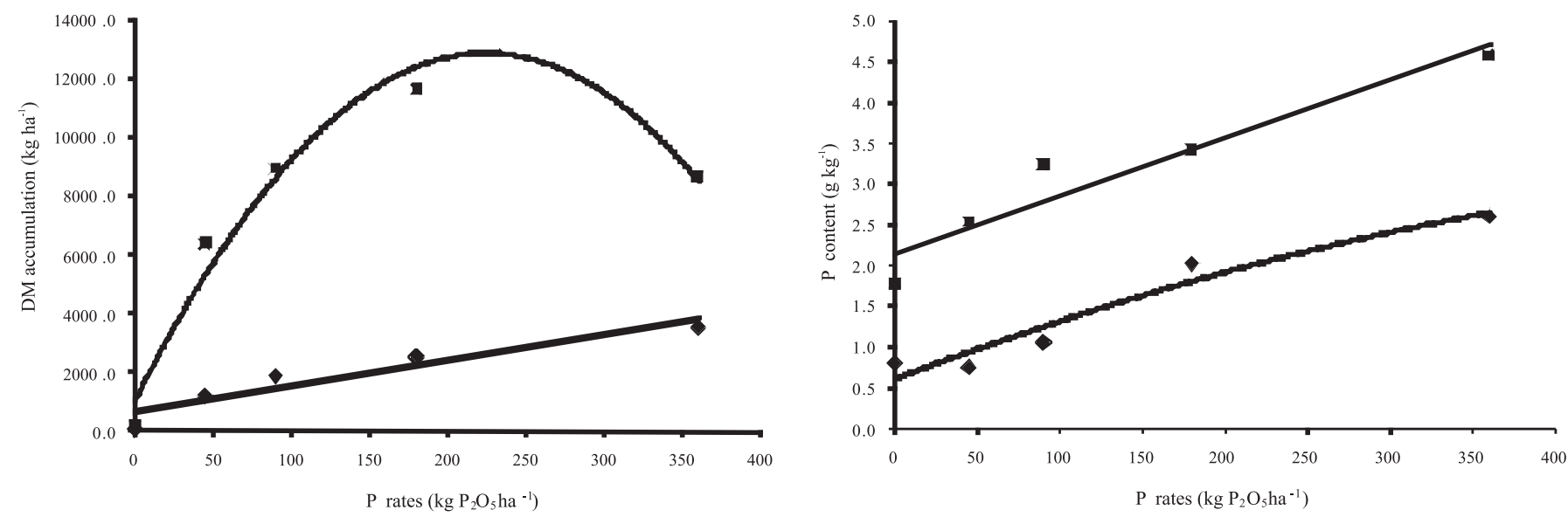

Figure 9 - Dry matter accumulation and P content for forage sorghum and ryegrass cropped under the residual effect of P.

$10000 \mathrm{~kg} \mathrm{ha}^{-1}$ was the sorghum maximum yield obtained when $180 \mathrm{~kg}$ of $\mathrm{P}_{2} \mathrm{O}_{5}$ ha $^{-1}$ was applied. This yield was close to the values obtained by Moraes (2001) and Torres et al. (2008). Unlike yield, P concentration followed a linear behavior, reaching values above the $3.0 \mathrm{~g} \mathrm{~kg}^{-1}$ required by cattle.

Positive response to $\mathrm{P}$ application was also observed in the second year of ryegrass crop. However, unlike the first year, the ryegrass yield showed linear increment due to $\mathrm{P}$ supply. This result suggests that it is worth applying high levels of $\mathrm{P}$ fertilizer, since the yield could be maintained for long period. Also, there was a direct relation of $P$ concentration and $P$ rates. As a matter of fact, residual effect of $P$ application was observed on ryegrass yield and quality.

\section{Conclusions}

Phosphorus fertilization increases soil phosphorous availability and consequently, phosphorus content in the plant tissue and ryegrass dry matter accumulation, although there is no effect of $\mathrm{P}$ rates in the plant tissue $\mathrm{N}$ and $\mathrm{C}$ concentrations. Phosphorous rates increased ryegrass roots density; the rate of $45 \mathrm{~kg} \mathrm{P}_{2} \mathrm{O}_{5} \mathrm{ha}^{-1}$ is effective for maximum root development. In this sense, ryegrass plants under phosphorus deficiency tend to invest in root development instead of above-ground biomass and the opposite occurs under high $\mathrm{P}$ rates.

\section{References}

BANDINELLI, D.G.; GATIBONI, L.C.;TRINDADE, J.P.P. et al. Composição florística de pastagem natural afetada por fontes de fósforo, calagem e introdução de espécies forrageiras de estação fria. Ciência Rural, v.35, n.1, p.84-91, 2005.
BHADORIA, P.S.; EL DESSOUGI, H.; LIEBERSBACH, H. et al. Phosphorus uptake kinetics, size of root system and growth of maize and groundnut in solution culture. Plant and Soil, v.262, p.327-336, 2004.

BRANDON, D.M.; GRIFFIN, J.L.; WILSON JR., F.E. et al. Effect of $\mathrm{P}$ fertilization on performance of wheat immediately following Rice and one year following rice. In: ANNUAL PROGRESS REPORT, 73., 1981, Louisiana. Proceedings... Louisiana: Rice Experiment Station, 1981. p.120-137.

CECATO, U.; SKROBOT, V.D.; FAKIR, G.R. et al. Perfilhamento e características estruturais do capim-Mombaça, adubado com fontes de fósforo, com pastejo. Revista Acta Scientiarum: Animal Science, v.30, n.1, p.1-7, 2008.

CECATO, U.; YANAKA, F.Y.; BRITO FILHO, M.R.T. et al. Influência da adubação nitrogenada e fosfatada na produção, na rebrota e no perfilhamento do capim-marandu (Brachiaria brizantha (Hochst) Stapf. Cv. Marandu). Revista Acta Scientiarum, v.22, n.3, p.817-822, 2000.

COMISSÃO DE FERTILIDADE DO SOLO - RS/SC. Manual de adubação e de calagem para os estados do Rio Grande do Sul e de Santa Catarina. 10.ed. Porto Alegre: SBCS - Núcleo Regional Sul: UFRGS, 2004. 400p.

EMPRESA BRASILEIRA DE PESQUISA AGROPECUÁRIA EMBRAPA. Sistema brasileiro de classificação de solos. 2.ed. Rio de Janeiro: Embrapa Solos, 2006. 306p.

GATIBONI, L.C.; KAMINSKI, J.; PELLEGRINI, J.B.R. et al. Influência da adubação fosfatada e da introdução de espécies forrageiras de inverno na oferta de forragem de pastagem natural. Pesquisa Agropecuária Brasileira, v.35, n.8, p.1663-1668, 2000.

GATIBONI, L.C.; KAMINSKI, J.; RHEINHEIMER, D.S. et al. Superphosphate and rock phosphates as P-source for grassclover pasture on a limed acid soil of Southern Brazil. Communications in Soil Science and Plant Analysis, v.34, n.17\&18, p.2503-2514, 2003.

GHERI, E.O.; CRUZ, M.C.P.; FERREIRA, M.E. et al. Nível crítico de fósforo para Panicum maximum Jacq. cv. Tanzânia. Pesquisa Agropecuária Brasileira, v.35, p.1809-1816, 2000.

HAJABBASI, M.A.; SCHUMACHER, T.E. Phosphorus effects on root growth and development in two maize genotypes. Plant and Soil, v.158, p.39-46, 1994.

HECKMAN, J.R.; JOKELA, W.; MORRIS, T. et al. Soil test calibration for predicting corn response to phosphorus in the Northeast USA. Agronomy Journal, v.98, p.280-288, 2006. 
JONES, D.B. Factors for converting percentages of nitrogen in foods and feeds into percentages of protein. Washington: United States Department, 1931. p.1-21. (Circular, 183).

KANNO, T.; MACEDO, M.C.M.; UOZUMI, S. et al. Development of grasslands. Management technology for sustainable agropastoral systems in the sub-tropical zone in Brazil. JIRCAS Working Report, v.19, p.63-73, 2001.

LEMAIRE, G.; SALETTE, J. Relation entre dynamique de croissance et dinamique de prévèlement d'azote pour un peuplement de graminées fourragères. I. Etude de l'effet du milieu. Agronomie, v.4, p.423-430, 1984.

MANARIN, S.A. Combinações de doses de fósforo e de zinco em solução nutritiva para o capim Tanzânia. Piracicaba: USP/ESALQ, 2005. 81p. (Livre-Docência).

MARASCHIN, G.E.; ALMEIDA, E.X.; HARTHMANN, O.E.L. Pasture dynamics of 'Mott' dwarf elephantgrass as related to animal performance. In: INTERNATIONAL GRASSLAND CONGRESS, 18., 1997, Canada. Proceedings... Canada, 1997. p.29/25-29/26.

MARTHA, G.; CORSI, M. Pastagens no Brasil: Situação atual e perspectivas. Preços Agrícolas, v.15, n.170, p.3-6, 2001.

MARTINS, A.P.L; REISSMANN, C.B. Material vegetal e as rotinas laboratoriais nos procedimentos químico-analíticos. Revista Scientia Agraria, v.8, n.1, p.1-17, 2007.

MELO, S.P.; MONTEIRO, F.A.; MANFREDINI, D. Silicate and phosphate combinations for Marandu palisadegrass growing on an oxisol. Revista Scientia Agricola, v.64, n.3, p.275-281, 2007.

MESQUITA, E.E., PINTO, J.C.; FURTINI NETO, A.E. et al. Teores críticos de fósforo em três solos para o estabelecimento de Capim mombaça, Capim marandu e Capim andropogon em vasos. Revista Brasileira de Zootecnia, v.33, p.290-301, 2004.

MORAES, R.N.S. Decomposição das palhadas de sorgo e milheto, mineralização de nutrientes e seus efeitos no solo e na cultura do milho em plantio direto. 2001. $90 \mathrm{f}$. Dissertação (Mestrado em Fitotecnia) - Universidade Federal de Lavras, Lavras.

NATIONAL RESEARCH COUNCIL - NRC. Nutrient requirements of beef cattle. 7.ed. Washington: National Academy Press, 1996. 242p.

OLIVEIRA, T.N.; PAZ, L.G.; SANTOS, M.V.F. et al. Influência do fósforo e de diferentes regimes de corte na produtividade e no perfilhamento do capim-de-raiz (Chloris orthonoton Doell). Revista Brasileira de Zootecnia, v.33, p.60-67, 2004.
OLSZEWSKA, M.; GRZEGORCZYK, S.; OLSZEWSKI, J. et al. Effect of phosphorus deficiency on gas exchange parameters, leaf greenness (SPAD) and yield of Perennial ryegrass (Lolium perenne L.) and Orchard grass (Dactylis glomerata L.). Journal of Elementology, v.13, n.1, p.91-99, 2008.

RIZO, L.M.; MOOJEN, E.L.; QUADROS, F.L.F. et al. Desempenho de pastagem nativa e pastagem sobre-semeada com forrageiras hibernais com e sem glifosato. Ciência Rural, v.34, n.6, p.1921-1926, 2004.

ROSOLEM, C.A.; MARCELLO, C.S. Crescimento radicular e nutrição mineral da soja em função da calagem e adubação fosfatada. Revista Scientia Agricola, v.55, n.3, p.448-455, 1998.

SCHUNKE, R.M.; VIEIRA, J.M.; SOUSA, J.C. et al. Resposta à suplementação fosfatada e à suplementação mineral de bovinos de corte sob pastejo em Brachiaria decumbens. Campo Grande: EMBRAPA-CNPGC, 1991. 24p. (Boletim de Pesquisa, 5).

SHENK, M.K.; BARBER, S.A. Root characteristics of corn genotypes as related to P uptake. Agronomy Journal, v.71, p.921-924, 1977.

THÉLIER-HUCHÉ，L.; FARRUGGIA，A.; CASTILLON，P. L'analyse d'herbe: un outil pour phosphate et potassique des prairies naturelles et temporaries. Paris: Plaquette COMIFERACTA, Institut de l'Elevage-ITCF, 1999. 31p.

TOKARNIA, C.H.; DÖBEREINER, J.; PEIXOTO, P.V. Deficiências minerais em animais de fazenda, principalmente bovinos em regime de campo. Pesquisa Veterinária Brasileira, v.20, n.3, p.127-138, 2000.

TORRES, J.L.R.; PEREIRA, M.G.; FABIAN, A.J. Produção de fitomassa por plantas de cobertura e mineralização de seus resíduos em plantio direto. Pesquisa Agropecuária Brasileira, v.43, n.3, p.421-428, 2008.

TRINDADE, D.S.; CAVALHEIRO, A.C.L. Concentrações de fósforo, ferro e manganês em pastagens nativas do Rio Grande do Sul. Revista da Sociedade Brasileira de Zootecnia, v.19, n.1, p.44-57, 1990.

WELCH, L.F.; BOONE, L.V. How fertilizer affects field drying of corn. Spring: Illinois Research, 1968. p.3-4.

ZADA, K.; KARIM, M. Effect of phosphorus and late sowing on grain yield, maturity and grain weight of barley. Pakistan Journal of Agriculture Research, v.3, n.4, p.224-227, 1982. 